\title{
Diagnostics of company processes
}

\author{
Elena Ganebnykh ${ }^{1,{ }^{*}}$, Olga Lezhnina $^{2}$, Julia Zhukova $^{2}$ and Valentina Kashintseva ${ }^{3}$ \\ ${ }^{1}$ Vyatka State University, 36, Moskovskaya str., 610000, Kirov, Russia \\ ${ }^{2}$ Vyatka State Agricultural Academy, 133, October Avenue, 610017, Kirov, Russia \\ ${ }^{3}$ Moscow State University of Civil Engineering, 26, Yaroslavskoye Shosse, 129337, Moscow, Russia
}

\begin{abstract}
The article deals with the company's transition to management based on a process approach. This approach is the basis for the introduction of lean-production, which has been especially popular in recent years in Russia. Company executives do not always understand how to start changes. The authors have developed diagnostic matrices in three areas: Management Processes, Organizational Culture, and Organizational Systems. Using an expert assessment of the proposed criteria, the manager can understand the current level of company development and identify problems in each area. Developed diagnostic matrices consider the analysis of processes in the dynamics of transformation of company policy from reactive to proactive.
\end{abstract}

\section{Introduction}

The effectiveness and quality of company management are determined by the validity of the methodology for solving problems, i.e. approaches, principles, methods. Modern management theory and practice offers different approaches to activity management: functional management [1,2], project management [3], and process management [4]. A business process coordinates the behavior of people, systems, information and things to produce business outcomes in support of a business strategy [5].

The methodology of lean manufacturing, which is popular in Russia today, is based on a process approach. The whole company is considered as a set of interconnected processes, and processes are evaluated from the position of customer value. Russian practice has many problems while implementing lean manufacturing. According to John Maleyeff, the main barriers to lean manufacturing are:

- Inconsistent leadership motivation;

- Management competency in process improvement;

- Culture that considers time devoted to improvement less valuable than time devoted to "real work";

- Union rules and relations;

- Technical skill of employees;

\footnotetext{
*Corresponding author: ganebnykh@mail.ru
} 
- Many undocumented processes [6].

Russian practice especially emphasizes the barriers associated with resistance to changes in the company. According to D.L. Savenkov, the use of lean manufacturing tools in the industrial sector of the economy, points out the following key problems:

1) incorrect determination of the main restrictions and sources of loss of production resources of the enterprise;

2) significant barriers to involving employees of medium and large industrial enterprises in the process of lean-changes;

3 ) involvement of an external specialist in the field of lean manufacturing, who does not know the specifics of the enterprise;

4) imbalances in stimulating the implementation of kaizen plans in relation to a narrow initiative group of lean specialists and a wide range of other performers [8].

Markova N.A. and Markov D.A. divide these barriers into five categories: motivation, training, leadership, culture and structure [7].

V.V. Glukhov, E.S. Balashov point out that managing the process of increasing the efficiency of an enterprise based on the use of lean-production techniques can lead to two groups of problems. Firstly, the staff can take the lean concept as completely unknown, not related to real industrial production. Lean-initiatives can be considered as an additional burden for employees, and the process of increasing the productivity of each employee can be assessed as the basis for dismissing a certain number of subordinates and managers. Secondly, the process of continuous step-by-step improvement, implemented within the kaizen plans, may reduce output connected with obsolete equipment at the enterprise [9].

Most researchers describe global implementation problems, while managers often cannot build a process model for their company, describe and diagnose their processes. Diagnostics of processes, together with determining the level of development of the company in different directions, show the "weakest" areas. It must be considered when defining lean-production launch points.

\section{Methods and Materials}

The aim of the study is to develop diagnostic forms for the initial assessment of the company's processes in various areas. Tasks of the diagnostic are:

- to define processes and functions;

- to measure the level of company development in the chosen processes;

- to analyze directions of company development in order to determine priorities.

The research methodology is based on the workflow management system principle (WMS). It allows to create an infrastructure for the description and evaluation of certain areas of activity, and also helps to monitor the status (state change) of the system parameters. WMS can assign individual steps requiring deploying human intuition or judgment to relevant tasks.

In the course of the study, the model of company operational efficiency was analyzed in three areas: management processes, organizational culture, and organizational systems. Toni Doolen et al. describe the components of these directions in detail (Table 1) [10].

Table 1. Organizational Context Classification and Variables.

\begin{tabular}{|l|}
\hline \multicolumn{1}{|c|}{ Management Processes } \\
\hline - Extend to which management processes have helped to create a clearly defined purpose and \\
clear goals for the team (CP) \\
- Extend to which management processes have helped to create alignment between team \\
goals and the goals of the parent organization (GA) \\
- Extend to which management processes support the team through the allocation of critical \\
\hline
\end{tabular}




\begin{tabular}{|l|}
\hline \multicolumn{1}{|c|}{ Organizational Culture } \\
\hline - Extend to which the organizational culture supports positive inter-team interactions such as \\
communications and cooperation between teams in the organization (II) \\
- Extend to which the organizational culture supports the integration of the team into the rest \\
of the organization (TI) \\
- Extend to which the organizational culture supports values and supports teams and \\
teamwork (TT) \\
\hline \multicolumn{1}{c|}{ Organizational Systems } \\
\hline - Extend to which organizational systems provide team-level feedback and recognition (FR) \\
- Extend to which organizational systems provide teams with the necessary business and \\
technical information (IS) \\
- Extend to which organizational systems provide the necessary training for teams (TR) \\
\hline
\end{tabular}

The largest Russian companies, pioneers in the implementation of the process approach Sberbank, Sibur, Gazprom Neft and others, use the same technique. Due to the confirmed effectiveness of this decomposition of the approach, the authors have taken it as the basis for the development of diagnostic forms.

Experts evaluate the provisions placed in diagnostic forms using the binary system (1 yes, 0 - no). The provisions are grouped sequentially, forming groups corresponding to the reactive, preventive or proactive policies of the company. Further analysis of expert opinions allows to assess the position of the company in each direction.

\section{Results}

The Management Processes section should be considered in the context of five categories: optimization of flows and operations, optimization of the workspace, equipment and machinery management, competency management of employees, standardization of work.

The company's reactive policy towards Management Processes is characterized by an analysis of operations only when necessary. In such organizations, improvements are pointbased, including workspace optimization. Typically, jobs are created at the beginning, and then nothing changes for years. Only emergency repairs are carried out for equipment and machinery. At the same time, if the company has nominally developed, but not implemented schedules for preventive maintenance, its policy will also be considered reactive. There are cases when a company has already realized and started collecting statistics on equipment downtime, unplanned accidents, causes of accidents, the quality of components for repairs, and so on. It does not indicate a transition to the preventive phase, since data collection may not reach practical application in the concept of total productive maintenance (TPM). Regarding the competence of employees, usually job requirements are below professional standards. There is no combination of professions, often the number of employees is higher than required, there is part-time employment or people are underloaded. In general, work in the company is carried out at the level of legislative requirements, including the field of standardization. The requirements, the failure of which may result in fines or other serious consequences, are fulfilled (for example, labor protection).

The company's preventive policy is characterized by a higher level of development of Management Processes. Employees of the company see wastes in their processes and suggest improvements. The results of process improvement are fixed in the standards (or whether changes are made to existing standards). Changes in the KPI of the process are assessed after elimination of losses (before/after). Equipment performance indicators are regularly monitored (OEE, Overhaul Period, Average Repair Time, etc.). Corrective actions are prescribed for deviations from the target value. The company has a schedule of 
preventive work and this schedule is actually being implemented. The company also analyzes the reasons for unplanned downtime of the equipment, and the schedule is constantly adjusted according to it. As for the personnel, a preventive policy allows to periodically evaluate the qualifications of employees and also train them (improve qualifications) in accordance with the developed plan. Mentoring and adaptation programs for beginners are developed in such a company.

The proactive policy of the company means a systematic search for wastes and planning improvment processes at least for the medium term. Such companies analyze internal flows, pay attention to suppliers and other external factors that have an impact on operational efficiency. Employees of such companies are provided with conditions for continuous development. The training system is built in accordance with the market situation. The diagnostic matrix of the direction of Management Processes is presented in Table 2 .

Table 2. Diagnostic Matrix of Management Processes.

\begin{tabular}{|c|c|c|c|}
\hline Direction & Questions / Evaluation Options & $0 / 1$ & Level \\
\hline \multirow{8}{*}{ 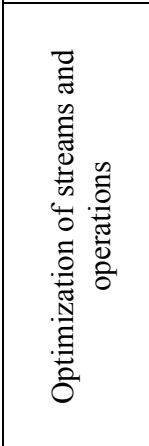 } & Analysis of operations is carried out when necessary. & & \multirow{2}{*}{ React } \\
\hline & Improvements are spotty & & \\
\hline & $\begin{array}{l}\text { Employees see wastes in their processes and offer suggestions } \\
\text { for improvements }\end{array}$ & & \multirow{3}{*}{ Prevent } \\
\hline & Process improvement results are fixed in standards & & \\
\hline & $\begin{array}{l}\text { There is an assessment of changes in the KPI process after } \\
\text { eliminating losses (before/after) }\end{array}$ & & \\
\hline & Employees use process analysis tools to improve processes & & \multirow{3}{*}{ Proact } \\
\hline & $\begin{array}{l}\text { External wastes and their impact are clearly defined, } \\
\text { improvement programs are developed and implemented }\end{array}$ & & \\
\hline & $\begin{array}{l}\text { Improvements are systemic. Continuous loss search is everyday } \\
\text { work }\end{array}$ & & \\
\hline \multirow{3}{*}{ 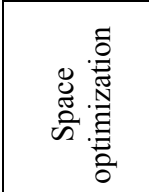 } & Optimization of workplaces and building layouts are spotty & & React \\
\hline & Jobs are organized in accordance with the principles of $5 \mathrm{C}$ & & Prevent \\
\hline & $\begin{array}{l}\text { Equipment / offices / departments / workshops are located in } \\
\text { accordance with the results of flow analysis }\end{array}$ & & Proact \\
\hline \multirow{9}{*}{ 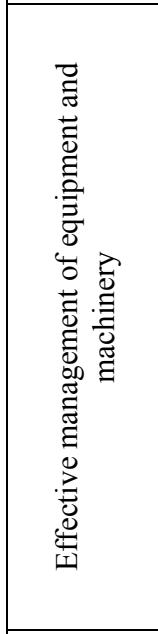 } & There is nominal documentation for scheduled maintenance & & \multirow[b]{2}{*}{ React } \\
\hline & $\begin{array}{l}\text { There is statistics on equipment downtime connected with } \\
\text { unplanned repairs }\end{array}$ & & \\
\hline & $\begin{array}{l}\text { The reasons for unplanned downtime of the equipment are } \\
\text { analyzed, corrective measures are developed }\end{array}$ & & \multirow{4}{*}{ Prevent } \\
\hline & $\begin{array}{l}\text { Equipment performance indicators are monitored monthly. } \\
\text { Corrective actions are prescribed for deviations from the target } \\
\text { value. }\end{array}$ & & \\
\hline & Schedule preventive maintenance is strictly adhered to. & & \\
\hline & $\begin{array}{l}\text { The company has a training program for operators of } \\
\text { autonomous equipment maintenance }\end{array}$ & & \\
\hline & $\begin{array}{l}\text { The analysis of the criticality of breakdowns for all types of } \\
\text { equipment is carried out }\end{array}$ & & \multirow{3}{*}{ Proact } \\
\hline & $\begin{array}{l}\text { Analysis of the effectiveness of scheduled maintenance is } \\
\text { embedded in monthly activities. Reliability analysis of parts } \\
\text { suppliers is carried out }\end{array}$ & & \\
\hline & The number of unplanned repairs is $<5 \%$ & & \\
\hline \multirow{2}{*}{ 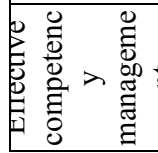 } & $\begin{array}{l}\text { There is a primary system of testing the necessary knowledge } \\
\text { and skills for each profession }\end{array}$ & & React \\
\hline & $\begin{array}{l}\text { A system for identifying staff competencies, skills and abilities } \\
\text { is used }\end{array}$ & & Prevent \\
\hline
\end{tabular}




\begin{tabular}{|c|c|c|}
\hline & $\begin{array}{l}\text { Assessment of the competencies of employees is carried out at } \\
\text { least once a year }\end{array}$ & \\
\hline & $\begin{array}{l}\text { Training programs are updated every six months and are } \\
\text { monitored for all employees }\end{array}$ & \\
\hline & $\begin{array}{l}\text { Training of employees is carried out in accordance with the } \\
\text { training plan }\end{array}$ & \\
\hline & Training programs are timely adjusted & \\
\hline & $\begin{array}{l}\text { Job descriptions are prepared for all levels and roles, the } \\
\text { qualifications for success in the organization are clearly defined }\end{array}$ & \\
\hline & Introductory training program is developed for new employees & \\
\hline & $\begin{array}{l}\text { There is a systematic education and training programs (TWI, } \\
\text { monitoring, seminars, self-education) }\end{array}$ & Drosent \\
\hline & $\begin{array}{l}\text { Employees are provided with the conditions for continuous } \\
\text { development }\end{array}$ & Proact \\
\hline \multirow{5}{*}{ 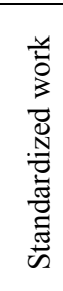 } & The organization has only mandatory standards & React \\
\hline & $\begin{array}{l}\text { The need for standards development has been identified. A } \\
\text { standardization plan for the current year has been developed. }\end{array}$ & \multirow[t]{2}{*}{ Prevent } \\
\hline & Standards are developed by the manager or individual specialists & \\
\hline & $\begin{array}{l}\text { Verification of compliance with the requirements of standards in } \\
\text { the work of employees is carried out. }\end{array}$ & \multirow{2}{*}{ Proact } \\
\hline & $\begin{array}{l}\text { Employees are involved in continuous improvement of } \\
\text { standards. }\end{array}$ & \\
\hline
\end{tabular}

The Organizational Culture department reflects the customer focus of the company in general, the relationship of management with subordinates, teamwork and the involvement of employees in the improvement process.

The reactive policy of Organizational Culture is characterized by the collection of customer complaints. In rare cases, a feedback collection system is also organized, but most often the feedback analysis is spotty, the perpetrators are identified, an indicative punishment is carried out, however, there are no cardinal changes. In such companies, an authoritarian style of leadership prevails, critical opinions are crushed, information accessibility is limited [11]. Information restrictions lead to narrow and fragmented goals of structural units.

The preventive policy of Organizational Culture are characterized by a systematic analysis of feedback on the development of change programs. The leader seeks to create a favorable atmosphere not only for himself, but for the whole team. The company welcomes teamwork, quality circles or their analogues. The company has approved and used a system for submitting proposals for improvement, as well as a motivational reward program for submitting proposals, improving processes.

The proactive policy of Organizational Culture is characterized by the transition of consumer voice into CTQ indicators. In such a company, there is a practice of researching customer satisfaction, researching customer expectations. The leader teaches others by actively delegating complex tasks and helps in solving problems. The problem solving teams involve not only working groups of company specialists, but also customers, representatives of suppliers, service organizations and so on. Table 3 presents the diagnostic matrix of Organizational Culture. 
Table 3. Diagnostic Matrix of Organizational Culture.

\begin{tabular}{|c|c|c|c|}
\hline 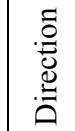 & Questions / Evaluation Options & $0 / 1$ & Level \\
\hline \multirow{7}{*}{ 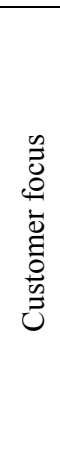 } & $\begin{array}{l}\text { There is an organized a system for collecting complaints from external } \\
\text { customers }\end{array}$ & & \multirow[t]{2}{*}{ React } \\
\hline & There is a system for receiving feedback from external clients & & \\
\hline & $\begin{array}{l}\text { The analysis of the received feedback is carried out. An action plan is } \\
\text { formed to eliminate identified deviations }\end{array}$ & & \multirow{3}{*}{ Prevent } \\
\hline & $\begin{array}{l}\text { An assessment of customer satisfaction is carried out. There is "Customer } \\
\text { Voice" (general understanding of customer needs, desires, perceptions } \\
\text { and preferences regarding a product / service). }\end{array}$ & & \\
\hline & Customer focus standards are developed & & \\
\hline & Consumer voice rating transforms into CTQ & & \multirow[b]{2}{*}{ Proact } \\
\hline & $\begin{array}{l}\text { There is a practice of researching customer satisfaction, customer } \\
\text { expectations }\end{array}$ & & \\
\hline \multirow{6}{*}{ 离 } & An authoritarian management style prevails in the company & & \multirow{2}{*}{ React } \\
\hline & Leaders have a predominantly administrative role & & \\
\hline & $\begin{array}{l}\text { The leader seeks to create a favorable atmosphere not only for himself, } \\
\text { but for the whole team }\end{array}$ & & \multirow{3}{*}{ Prevent } \\
\hline & $\begin{array}{l}\text { The leader is productive and stimulates employees to work productively } \\
\text { by personal example }\end{array}$ & & \\
\hline & The leader involves employees in the improvement process & & \\
\hline & $\begin{array}{l}\text { The leader teaches others by actively delegating complex tasks and } \\
\text { helping to solve problems }\end{array}$ & & Proact \\
\hline \multirow{6}{*}{ 产 } & The efficiency / effectiveness of a department depends on certain people & & \multirow{2}{*}{ React } \\
\hline & $\begin{array}{l}\text { Heads of departments (sections, workshops, etc.) are determined to } \\
\text { protect their interests, rather than achieving the goals of the organization. }\end{array}$ & & \\
\hline & Working groups are organized to search for reserves & & \multirow[b]{2}{*}{ Prevent } \\
\hline & Workgroup members are trained in lean tools and teamwork & & \\
\hline & $\begin{array}{l}\text { All employees are eager to improve performance, ready to participate in } \\
\text { the search and solution of problems. Working groups constantly set new } \\
\text { goals and solve problems at higher levels }\end{array}$ & & \multirow{2}{*}{ Proact } \\
\hline & $\begin{array}{l}\text { The problem solving teams include customers, representatives of } \\
\text { suppliers, service organizations, etc. }\end{array}$ & & \\
\hline \multirow{5}{*}{ 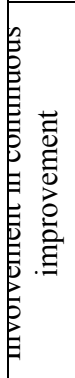 } & Employees periodically take the initiative and suggest improvements & & React \\
\hline & Proposal submission system is approved and functioning & & \multirow{3}{*}{ Prevent } \\
\hline & $\begin{array}{l}\text { The motivation system for submitting proposals, improving processes has } \\
\text { been approved and is functioning }\end{array}$ & & \\
\hline & There is a practice of immediate standardization of a positive result & & \\
\hline & $\begin{array}{l}\text { Measurements, analysis, and search for opportunities to improve } \\
\text { operations are constantly carried out. Over } 80 \% \text { of employees make } \\
\text { suggestions for improving operations }\end{array}$ & & Proact \\
\hline
\end{tabular}

The Organizational Systems section includes the deployment of corporate policies and strategic goals, accounting and problem solving, process management and the production system. 
The reactive policies of Organizational Systems are characterized by the setting of common goals, which are not always methodologically SMART ones. Problems are considered by line managers, measures to solve problems are formed, those responsible for solving problems are appointed, deadlines are set. Such companies do not always have a clearly defined organizational structure; employees don't want responsibility for their job duties. If we talk about companies that have decided to begin the implementation of leanproduction, then they usually have an annual budget for the implementation project, and the head or the corresponding specialist develops a plan for implementing the system with a Gant chart.

The preventive policy of Organizational Systems is characterized by SMART goals that are decomposed to the level of structural units / departments / sections / specific employees. Leaders know the TOP-3 problems for each indicator of their process; there are plans to deal with the root causes of these problems. Employees use basic analysis tools (e.g. Pareto diagram, Ishikawa diagram, 5 Whys, A3 Problem Solving etc.). The company has developed and implemented a process model and a matrix for the distribution of responsibility for processes, prioritized processes, they are described, their indicators are determined.

The proactive policy of Organizational Systems are characterized by information accessibility. Continuous improvement system activities are integrated into annual, monthly, weekly and daily routine work. The diagnostic matrix of Organizational Systems is presented in Table 4.

Table 4. Diagnostic Matrix of Organizational Systems.

\begin{tabular}{|c|c|c|c|}
\hline 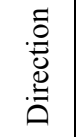 & Questions / Evaluation Options & $0 / 1$ & Level \\
\hline \multirow{10}{*}{ 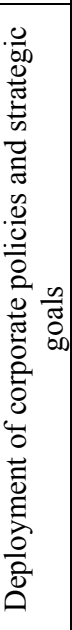 } & The goals of the organization for the current year are defined & & \multirow[b]{2}{*}{ React } \\
\hline & $\begin{array}{l}\text { Action plans for achieving goals are developed and approved at the } \\
\text { level of structural units }\end{array}$ & & \\
\hline & $\begin{array}{l}\text { The organization's goals are divided into elements (for example: Safety, } \\
\text { Quality, On-Time Order Fulfillment, Costs, Culture). There is a } \\
\text { responsible emplyee for each area }\end{array}$ & & \multirow{7}{*}{ Prevent } \\
\hline & Organization goals meet SMART criteria & & \\
\hline & $\begin{array}{l}\text { Organization goals are decomposed to the level of structural units / } \\
\text { departments / sections / specific employees }\end{array}$ & & \\
\hline & $\begin{array}{l}\text { At each level of management, work is organized to track the } \\
\text { implementation of goals and activities systematically }\end{array}$ & & \\
\hline & At least $90 \%$ of goals are achieved & & \\
\hline & The organization's mission is formalized and known by all staff & & \\
\hline & The organization's strategy is formalized and known by all staff & & \\
\hline & $\begin{array}{l}\text { Employees participate in the formation of the plans and goals of the } \\
\text { company }\end{array}$ & & Proact \\
\hline \multirow{4}{*}{ 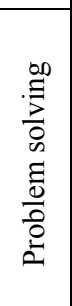 } & Information boards display current issues & & \multirow[b]{2}{*}{ React } \\
\hline & $\begin{array}{l}\text { Problems are considered by line managers, measures to solve problems } \\
\text { are formed, responsible emplyees for solving problems are appointed, } \\
\text { deadlines are fixed }\end{array}$ & & \\
\hline & $\begin{array}{l}\text { Attention is given to the main problems and causes. Leaders know the } \\
\text { TOP- } 3 \text { problems for each indicator of their process. There are plans to } \\
\text { deal with the main causes of these problems. }\end{array}$ & & \multirow[t]{2}{*}{ Prevent } \\
\hline & Problems are fixed and dealt with at the place of value creation & & \\
\hline
\end{tabular}




\begin{tabular}{|c|c|c|}
\hline & Employees use basic analysis tools & \\
\hline & Problem escalation system is designed and standardized & \\
\hline & Problem solving measures are standardized & \\
\hline & Employees use advanced analysis tools & \multirow{3}{*}{ Proact } \\
\hline & $\begin{array}{l}\text { If necessary, the employee can immediately access the necessary } \\
\text { information }\end{array}$ & \\
\hline & Best practices are implemented in all branches / workshops & \\
\hline \multirow{9}{*}{ 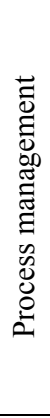 } & $\begin{array}{l}\text { The organizational structure is approved. Functions of departments and } \\
\text { employees are defined }\end{array}$ & \multirow{3}{*}{ React } \\
\hline & The organizational structure is real & \\
\hline & Employees fulfill their functional responsibilities & \\
\hline & $\begin{array}{l}\text { A process model and a matrix of distribution of responsibility for } \\
\text { processes are developed and implemented }\end{array}$ & \multirow{4}{*}{ Prevent } \\
\hline & Processes are prioritized & \\
\hline & Processes are described & \\
\hline & Process indicators are identified & \\
\hline & Each employee knows their consumer & \\
\hline & Processes are analyzed and constantly improved & Proact \\
\hline \multirow{7}{*}{ 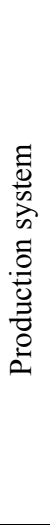 } & The organization plans to implement a continuous improvement system & \multirow{3}{*}{ React } \\
\hline & $\begin{array}{l}\text { A system of continuous improvement is implemented as a project. } \\
\text { Management has developed a Gantt chart system implementation plan }\end{array}$ & \\
\hline & An annual budget is defined for the implementation project & \\
\hline & $\begin{array}{l}\text { A system of continuous improvement is implemented and planned as } \\
\text { part of the organization. Projects to improve processes are pointed out. } \\
\text { Labor-intensive projects are divided into subprojects lasting 3-4 months }\end{array}$ & \multirow{3}{*}{ Prevent } \\
\hline & $\begin{array}{l}\text { For each improvement project, the following points are defined: Project } \\
\text { customer, Project manager, Project sponsor, Working group, Project } \\
\text { passport (charter), SMART goals, KPI, project budget, motivation } \\
\text { system }\end{array}$ & \\
\hline & The profit-cost ratio of projects is calculated & \\
\hline & $\begin{array}{l}\text { Continuous improvement system activities are integrated into annual, } \\
\text { monthly, weekly and daily routine work }\end{array}$ & Proact \\
\hline
\end{tabular}

The proposed diagnostic matrices show the main provisions of each direction in the context of the type of company policy. Matrices can be adjusted in accordance with the specifics of the company.

\section{Discussion}

The proposed diagnostic matrices suggest further analysis, which may be accompanied by infographics depicting the level of development in each component of the direction. Matrices can be detailed, not giving a generalized assessment for each type of policy, but, on the contrary, evaluating each item separately. It will provide a more accurate understanding of problem areas. An example of an infographic diagram is shown in Figure 1. 


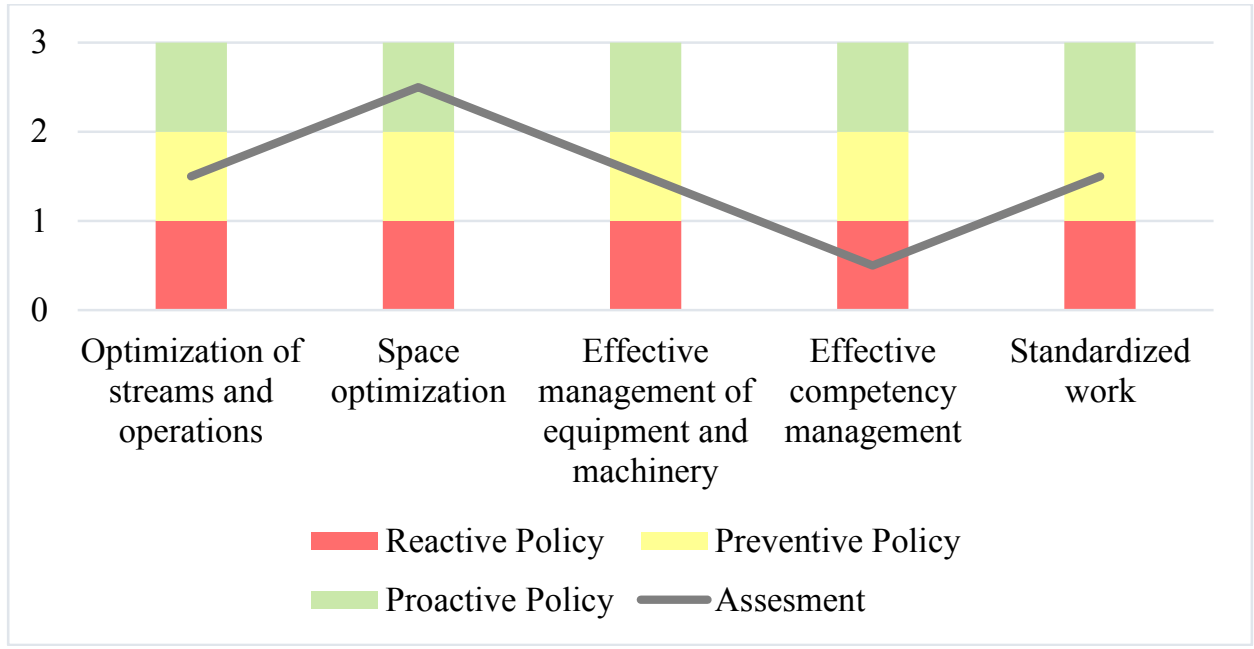

Fig. 1. Evaluation results of Management Processes.

The assessment chart indicates the implementation of a preventive policy in the company, but the indicator of employee competency management is a problem area. For a more accurate understanding, you can also correlate the results with an assessment by Organizational Culture. First of all, it is necessary to detail the problem area, prioritize and develop an action plan to change the situation. Probably, it is necessary to conduct certification of employees, identify missing competencies and plan staff training. Besides, it is necessary to find out extra competencies, identify personnel for the formation of a personnel reserve of managers and personnel for training in related professions.

The diagnosis of processes according to the developed matrices is the point correlation of indicators. Different sides of the same processes are displayed in each direction, so you can always clarify and detail the problem, look at it from different perspectives.

Another debatable point is the ability to collect expert opinions of leaders at different levels. It will allow to see the company through the eyes of different employees and will help to identify alternative opinions and their basis.

\section{Conclusion}

The introduction of a process approach to company management can give good results, and above all, it is the comprehension and reassessment of one's own activities. Managers often believe in the effectiveness of a method, but with a lack of understanding of how to implement it or a lack of qualified consultants. The developed diagnostic matrices can be the first simplest step in understanding the internal processes of the company and determining its current place and policy directions.

The proposed diagnostic matrices do not consider companies with passive policies. If a company carries out diagnostics of processes, then it responds to problems, which means it is aware of them. The first step in effective problem-solving is to identify the real problem you are trying to solve.

\section{References}

1. M. Hila, Management techniques: modern methods explained (2019) https://www.performancemagazine.org/management-modern-methods-explained/ 
2. M. Menz, Journal of Management 38(1), 45 (2012)

3. G. Cattani, S. Ferriani, L. Frederiksen, Advances in Strategic Management 28, 15 (2011)

4. S. Grimsley, Process Approach to Management: Definition \& Concept (2016) https://study.com/academy/lesson/process-approach-to-management-definition-lessonquiz.html

5. Business Process Management (BPM), Gartner Glossary https://www.gartner.com/en/information-technology/glossary/business-processmanagement-bpm

6. J. Maleyeff, Improving Service Delivery in Government with Lean Six Sigma (IBM Center for The Business of Government, 2007)

7. N. Markova, D. Markov, Upravlenets (The Manager) 6(9), 40 (2018)

8. A. Mottaeva, A. Ivashchenko, A. Ryattel, E3S Web of Conferences 164, 10038 (2020) https://doi.org/10.1051/e3sconf /202016410038

9. E. Vasilyeva, A. Mottaeva, E3S Web of Conferences 91, 08051 (2019) doi.org/10.1051/e3sconf /20199108051

10. T. Doolen, M. Hackler, E. Van Aken, Engineering Management, IEEE Transactions 50, 285 (2003)

11. E. Ganebnykh, O. Lezhnina, T. Zhilkina, E3S Web of Conferences 164, 10033 (2020) 